\title{
総合健診発見胆石の超音波断層像による分類
}

米澤 祐司, 善田 英美, 石濱 博之,
水野 勝介, 大崎 光, 瀬川 昂生

近年, 胆石症の非観血的な治療法として体外衝撃波 破砕療法（ESWL）が普及しつつある。その適応の決 定については種々の議論があるが，胆石の種類が大き な因子であることでは一致している。我々はその観点 に立ち，当施設の総合健診において発見された胆石を 腹部超音波検査所見を中心に検討した。

平成元年 7 月 1 日より平成 2 年 6 月 30 日までの 1 年間に総合健診の腹部超音波検査を受診した者は 7,728 名（男性 5,816 名，女性 1,912 名）であったが, その中で胆石症と診断された 316 名（男性 234 名, 女 性 82 名) を検討対象とした。発見率は男性 $4.0 \%$, 女 性 $4.3 \%$, 全体では $4.1 \%$ であり加齢と共に胆石保有 率が高くなった。

今回の検討は, 胆石の超音波画像と割面構造との対 比の結果考え出された土屋分類に従った。発見された 胆石症 316 例中, $10 \mathrm{~mm}$ 以上の大胆石 187 例を分類し た結果は次のと抢りである。I 型 78 例 (41\%)，II型 43 例 $(23 \%)$, III型 66 例 (36\%) で ESWL の最も良 い適応とされる I 型胆石は胆石症全体の $25 \%$ であっ た。また分類型別の頻度は男女間で有意差はなかった。 同様に小胆石 101 例を土屋に従って分類した結果は, 堆積型 40 例, 遊離型 38 例で, この 2 つの型が小胆石 全体の約 $80 \%$ を占めた。男女別にみると充満型胆石 は, 男性 12 例に対し女性は 1 例を認めるのみであった が，有意差は認められなかった。なお，対象 316 例中， 分類不能とした 28 例 $(8.9 \%$ ）はほとんどが 1 個ない し 2 個で存在する $5 \mathrm{~mm}$ 末満の小胆石であり, 個々の エコーの観察が困難であった。

次に $10 \mathrm{~mm}$ 以上の大胆石の保有者で, 腹部単純 X 線撮影と CT の両方を行った 67 名について超音波分 類型別に石灰化像の有無を検討した。結果は, 純コレ ステロール石が大多数を占め, 一部の混合石が相当す ると思われるI a 型 9 例はすべて両検査で石灰化像 を認めなかった。純コレステロール石あるいは混合石 に相当すると思われる I b 型 8 例は X 線撮影におい ては石灰化像は認められなかったが，そのうち 2 例は

\section{Ultrasonographic Classification of Gallstone Detected in the AMHTS}

愛知県総合保健センター
CT において辺縁あるいは辺縁の一部に軽度の石灰化 像が認められた。また混合石あるいは混成石に相当す ると思われる I c 型 9 例はすべて CT にて辺縁あるい は結石全体に軽度の石灰化像が認められた。これらの ことから， I 型胆石の亜分類は石灰化の有無と密接に 関係している考えられる。また，混合石，混成石ある いはビリルビンカルシウム石に相当すると思われる II 型, ビリルビンカルシウム石, 色素石に相当すると思 われるIII型は, 高頻度で石灰化像が認められ II 型, III 型胆石の石灰化の有無についても超音波型別との関連 性が認められた。

同様に両検査を行った $10 \mathrm{~mm}$ 未満の小胆石 23 例に ついて検討した。混合石に相当すると思われるものは 9 例であったが，そのうち堆積型-a, 堆積型-b, 浮遊 型を合わせた 6 例はいずれも CT で石灰化像が見られ 超音波型別のみでこれらの型の石灰化の有無を判断す ることは困難であると考えられる。また，色素石，混 合石, ビリルビンカルシウム石に相当すると思われる 堆積型-c, 遊離型の 3 例にはすべて石灰化像が認めら れた。

土屋分類と肥満度との関係の検討結果では, I 型胆 石すなわちコレステロール系胆石は肥満度の高い群に 多くみられた。逆に小胆石は肥満度の低い群に多く, この群には I 型胆石の保有者が有意に少なかった。な お同分類と血清コレステロール値との関係については 有意差はみられなかった。

〈まとめ〉 胆石の石灰化診断は大胆石の場合超音波 画像にてある程度可能である。小胆石の場合は CT 検 查を併用することにより正診率が高まると考えられ る。

ESWL の最も良い適応とされる I 型胆石は, 胆石症 全体の $25 \%$ であった。

コレステロール系胆石は肥満度の高い群に多く, 肥 満度の低い群には小胆石が多くみられた。

分類型別の頻度は男女間で有意差はなかった。 